\title{
KEPEMILIKAN DALAM ISLAM
}

\author{
Fadilah Ulfah \\ Program Studi Perbankan Syariah, Fakultas Ekonomi dan Bisnis Islam \\ Universitas Islam Negeri Alauddin Makassar \\ Email: fadillahulfa2017@gmail.com
}

\begin{abstract}
Abstrak
Pada dasarnya, kepemilikan merupakan pokok persoalan dalam aktivitas ekonomi manusia. Secara teologis, kepemilikan yang hakiki berada di tangan Allah Subhanahu Wa Ta'ala. Islam menggariskan bahwa kepemilikan senantiasa dipahami dalam dua dimensi, yaitu kepemilikan umum dan kepemilikan khusus. Kepemilikan umum berkaitan dengan karakter manusia sebagai makhluk sosial, sedangkan kepemilikan khusus berkaitan dengan manusia sebagai makhluk individu. Manusia harus diberikan ruang yang sama untuk mengakses sumber kekayaan umum. Tidak ada perbedaan didalamnya, mengingat manusia mempunyai kedudukan sama dihadapan Tuhan. Islam tidak membatasi bentuk maupun macam usaha bagi seseorang dalam memperoleh harta, begitupun Islam tidak membatasi pula kadar banyak sedikit hasil yang dicapai oleh usaha seseorang. Kepemilikan menurut KBBI berarti kepunyaan; hak, sehingga kepemilikan kemudian diartikan sebagai hal-hal yang berhubungan dengan milik baik berupa proses, perbuatan, dan cara memiliki, dalam Islam kepemilikan dikenal dengan nama al-milkiyah. Al-milkiyah memiliki arti yaitu sesuatu yang dimiliki dan dapat dimanfaatkan oleh seseorang, dan pengertian lain al-milk adalah pemilikian atas sesuatu (al-mal atau harta benda) dan kewenangan seseorang bertindak bebas terhadapnya. Kepemilikan dalam Islam itu sendiri, diklasifikasikan menjadi 3, yaitu; kepemilikan individu; kepemilikan umum; dan kepemilikan negara. Sedangkan berakhirnya sebuah kepemilikan ketika pemilik meninggal dunia, sehingga seluruh miliknya berpindah tangan kepada ahli warisnya, harta yang dimiliki itu rusak atau hilang, habisnya masa berlaku pemanfaatan atas sesuatu, barang yang dimanfaatkan rusak atau hilang, dan orang yang memanfaatkan meninggal dunia.
\end{abstract}

Kata Kunci: Kepemilikan, Al-Milkiyah, Harta 


\section{PENDAHULUAN}

Allah Subhanahu Wa Ta'ala menciptakan berbagai kekayaan sumber daya alam yang sangat luas dan tak terbatas. Ketidaksesuaian dalam pengelolaannya justru dapat menimbulkan perpecahan bahkan kesengsaraan bagi umat manusia. Dalam Islam, sumber daya alam yang termasuk milik umum seperti air, api, padang rumput, hutan dan barang tambang tidak boleh dikelola oleh individu, tetapi harus dikelola oleh negara yang hasilnya harus dikembalikan kepada rakyat.

Pada dasarnya, kepemilikan merupakan pokok persoalan dalam aktivitas ekonomi manusia. Secara teologis, kepemilikan yang hakiki berada di tangan Allah Subhanahu Wa Ta'ala. Islam menggariskan bahwa kepemilikan senantiasa dipahami dalam dua dimensi, yaitu kepemilikan umum dan kepemilikan khusus. Kepemilikan umum berkaitan dengan karakter manusia sebagai makhluk sosial, sedangkan kepemilikan khusus berkaitan dengan manusia sebagai makhluk individu. Manusia harus diberikan ruang yang sama untuk mengakses sumber kekayaan umum. Tidak ada perbedaan didalamnya, mengingat manusia mempunyai kedudukan sama dihadapan Tuhan.

Kepemilikan dalam syariat Islam adalah penguasaan terhadap sesuatu sesuai dengan aturan hukum, dan memiliki wewenang untuk bertindak terhadap apa yang ia miliki selama dalam jalur yang benar dan sesuai dengan hukum. Pada prinsipnya Islam tidak membatasi bentuk maupun macam usaha bagi seseorang dalam memperoleh harta, begitupun Islam tidak membatasi pula kadar banyak sedikit hasil yang dicapai oleh usaha seseorang. Hal ini tergantung pada kemampuan, kecakapan, dan ketrampilan masing-masing, asalkan dilakukan dengan halal dan wajar, artinya sah menurut hukum dan benar menurut ukuran moral dan akal juga tidak membahayakan individu maupun orang lain.

Mengingat begitu pentingnya aspek kepemilikan, maka dalam tulisan ini akan dipaparkan tentang Kepemilikan (almilkiyyah), yang menitik beratkan pada pembahasan tentang definisi kepemilikan, prinsip-prinsip kepemilikan, sebab-sebab kepemilikan, klasifikasi kepemilikan dalam Islam, serta berakhirnya kepemilikan dalam Islam. 


\section{PEMBAHASAN}

1. Definisi Kepemilikan

Kepemilikan menurut KBBI berarti kepunyaan; hak, sehingga kepemilikan kemudian diartikan sebagai hal-hal yang berhubungan dengan milik baik berupa proses, perbuatan, dan cara memiliki (Tatty, 2005).

Dalam Islam kepemilikan dikenal dengan nama al-milkiyah. Al- milkiyah secara etimologi berarti kepemilikan. Al-milkiyah memiliki arti yaitu sesuatu yang dimiliki dan dapat dimanfaatkan oleh seseorang, dan pengertian lain al-milk adalah pemilikian atas sesuatu (al-mal atau harta benda) dan kewenangan seseorang bertindak bebas terhadapnya. Ada beberapa pengertian tentang kepemilikan diantaranya yang dikemukakan oleh ulama fiqh antara lain seperti definisi Muhammad Musthafa alSyalabi adalah keistimewaan atas suatu benda yang menghalangi pihak lain bertindak atasnya dan memungkinkan pemiliknya melakukan perbuatan secara langsung atasnya selama tidak ada halangan syara'. Sedangkan definisi yang diungkapkan oleh ulama Wahbah al-Zuhaily dan Ahmad al-Zarqa tentang kepemilikan yaitu sama-sama menekankan hak dalam mempergunakan kewenangan kepada pemiliknya kecuali terdapat halangan hukum tertentu (Ambok, 2011).

Kepemilikan merupakan penguasaan seseorang terhadap sesuatu berupa barang atau harta, baik secara riil maupun secara hukum yang memungkinkan pemilik melakukan tindakan hukum, seperti jual beli, hibah, wakaf, dan sebagainya. Sehingga dengan kekuasaan ini orang lain baik secara individu maupun lembaga terhalang untuk memanfaatkan atau mempergunakan barang tersebut. Pada prinsipnya atas dasar kepemilikan itu, seseorang mempunyai keistimewaan berupa kebebasan dalam berbuat sesuatu atau tidak berbuat sesuatu kecuali ada halangan tertentu yang diakui syara' (Ali, 2012). 
2. Prinsip Dasar Kepemilikan Dalam Islam

Dalam konsep Islam ada beberapa prinsip dasar tentang kepemilikan, yaitu (Pratanto, 2020) :

a. Kekayaan merupakan titipan, pemilik yang sebenarnya adalah Allah Subhanahu Wa Ta'ala. Bahkan di dalam Al-Qur'an surah Ali-Imran : 189 dengan tegas menyatakan bahwa Allah Subhanahu Wa Ta'ala-lah pemilik mutlak segala sesuatunya.

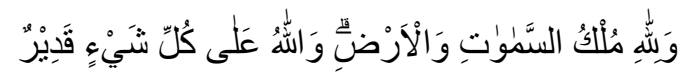

Artinya; Dan milik Allah-lah kerajaan langit dan bumi; dan Allah Mahakuasa atas segala sesuatu

Hal ini tidak berarti bahwa Allah Subhanahu Wa Ta'ala menciptakan segala sesuatunya itu untuk dirinya sendiri, namun Allah Subhanahu Wa Ta'ala Dalam alQuran dinyatakan dalam surat al-Baqarah ayat 29;

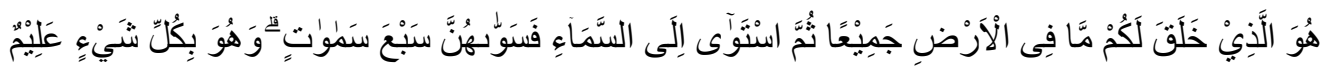

Artinya; Dialah (Allah) yang menciptakan segala apa yang ada di bumi untukmu kemudian Dia menuju ke langit, lalu Dia menyempurnakannya menjadi tujuh langit. Dan Dia Maha Mengetahui segala sesuatu.

Dalam ayat ini, Allah Subhanahu Wa Ta'ala menekankan bahwa apa yang telah diciptakan oleh-Nya adalah untuk dimiliki dan dimanfaatkan oleh umat manusia, namun hak-haknya ditentukan oleh batas-batas yang ditetapkan oleh-Nya.

Dengan demikian, hak kepemilikan seseorang tidaklah mutlak, tetapi terbatas dan memiliki persyaratan. Al-Quran menggambarkan sejumlah contoh dari orang orang yang merampas hak orang lain untuk kepentinganya sendiri dengan menimbun harta bendanya yang justru menyimpang dari batasan batasan yang telah ditetapkan oleh Allah Subhanahu Wa Ta'ala, bahkan mengangkat sesuatu berkedudukan pada kedudukan yang hanya diperuntukkan bagi Allah Subhanahu Wa Ta'ala. 
b. Harta yang di peroleh dapat menjadi penolong dalam menyempurnakan kewajiban manusia sebagai khalifah di bumi dan juga sarana untuk mendapatkan kesejahteraan dalam kehidupan sekarang maupun kehidupan di hari kemudian. Sehingga dalam Islam, terjadi pembatasan hak-hak bagi kepemilikan seseorang. Sebagaimana di dalam Al-Qur'an surah Di antara contoh pembatasan tersebut sebagaimana yang difirmankan Allah Subhanahu Wa Ta'ala dalam Al-Qur'an surah An-Nisa: 5 ;

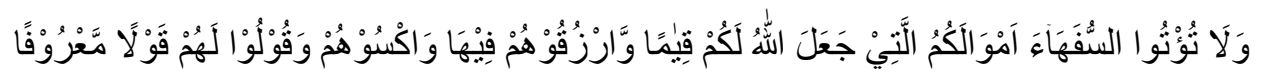

Artinya; Dan janganlah kamu serahkan kepada orang yang belum sempurna akalnya, harta (mereka yang ada dalam kekuasaan) kamu yang dijadikan Allah sebagai pokok kehidupan. Berilah mereka belanja dan pakaian (dari hasil harta itu) dan ucapkanlah kepada mereka perkataan yang baik.

c. Allah Subhanahu Wa Ta'ala telah melimpahkan kekayaan kepada setiap hamba-Nya untuk dipergunakan menunaikan kewajiban mereka seperti shalat dan zakat. Umat manusia sebagai suatu kesatuan dari setiap individu-individu manusia harus saling mengawasi proses kepemilikan dan penguasaan harta kekayaan tersebut dalam bentuk adanya, rasa persaudaraan, kebersamaan, saling membantu satu sama lain, sehingga akan membentuk fondasi utama bagi pertalian ekonomi antar manusia. Islam tidak memperbolehkan suatu perolehan dan peningkatan kekayaan seseorang terwujud dengan merampas nilai-nilai kemanusiaan. Karena kegunaan kekayaan tersebut adalah untuk menunjang dan menyempurnakan kelangsungan hidup manusia.

d. Hak-hak kepemilikan dalam Islam dipandang sebagai sebuah ujian. Allah Subhanahu Wa Ta'ala telah menetapkan aturan-aturan yang terkait hak-hak kepemilikan, berupa terbatasnya kebebasan individu dan adanya kewajiban untuk mentasharufkan kekayaan kepada orang-orang lain yang berhak. Aspek adanya keterbatasan kepemilikan individu dan adanya kepentingan sosial yaitu orang-orang yang membutuhkan dapat menjadikan umat mendapatkan keberhasilan dalam hidup. 
3. Klasifikasi Kepemilikan Dalam Islam

Kepemilikan dalam Islam diklasifikasikan menjadi 3 (tiga) jenis, yaitu (Sulistiawati \& Ahmad, 2017);

a. Kepemilikan individu

Kepemilikan individu adalah hukum syara' yang ditentukan pada zat ataupun kegunaan (utility) tertentu, yang memungkinkan siapa saja yang mendapatkannya untuk memanfaatkan barang tersebut, serta memperoleh kompensasi baik karena barangnya diambil kegunaannya oleh orang lain seperti disewa, ataupun karena dikonsumsi untuk dihabiskan zatnya seperti dibeli dari barang tersebut.

b. Kepemilikan umum adalah izin al-syari' kepada suatu komunitas untuk bersama-sama memanfaatkan benda atau barang. Sedangkan benda-benda yang tergolong kategori kepemilikan umum adalah benda-benda yang telah dinyatakan oleh al-Syari' sebagai benda-benda yang dimiliki suatu komunitas secara bersama-sama dan tidak boleh dikuasai oleh hanya seorang saja. Karena milik umum, maka setiap individu dapat memanfaatkannya, namun dilarang memilikinya, seperti fasilitas dan sarana umum, sumber daya alam yang tabiat pembentukannya menghalangi untuk dimiliki oleh individu secara perorangan, dan barang tambang yang depositnya tidak terbatas.

c. Kepemilikan Negara

Kepemilikan Negara adalah harta yang ditetapkan Allah menjadi hak seluruh rakyat, dan pengelolaannya menjadi wewenang khalifah atau negara, dimana negara berhak memberikan atau mengkhususkannya kepada sebagian rakyat sesuai dengan kebijakannya. Kepemilikan negara pada dasarnya juga merupakan hak milik umum, tetapi hak pengelolaannya menjadi wewenang dan tanggung jawab pemerintah. Meskipun demikian, cakupan kepemilikan umum dapat dikuasai oleh pemerintah, karena ia merupakan hak seluruh rakyat dalam suatu negara, yang wewenang pengelolaannya ada pada tangan pemerintah. 
4. Sebab-Sebab Kepemilikan Dalam Islam

Sebab-sebab kepemilikan harta adalah sebab yang menjadikan seseorang memiliki harta tersebut, yang sebelumnya tidak menjadi hak miliknya. Sebab pemilikan harta itu telah dibatasi dengan batasan yang telah dijelaskan oleh syara'. Menurut syari'at Islam setidaknya ada lima sebab kepemilikan (asbab altamalluk), yaitu (Aziz, 2019):

a. Bekerja (Al'amal)

Bentuk-bentuk kerja yang disyariatkan, sekaligus bisa dijadikan sebagai sebab kepemilikan harta, antara lain (Muhammad, 2016):

Menghidupkan Tanah Mati (ihya' almawaat)

Tanah mati adalah tanah yang tidak ada pemiliknmya, dan tidak dimanfaatkan oleh satu orangpun. Sedangkan yang dimaksud dengan menghidupkannya adalah mengolahnya dengan menanaminya atau dengan mendirikan bangunan di atasnya.

\section{Menggali kandungan bumi}

Menggali apa yang terkandung di dalam perut bumi, yang bukan merupakan harta yang dibutuhkan oleh suatu komunitas (jama'ah), atau disebut rikaz. Dengan kata lain, harta tersebut bukan merupakan hak seluruhnya kaum muslimn. Adapun jika harta temuan hasil penggalian tersebut merupakan harta yang dibutuhkan oleh suatu komunitas, atau merupakan hak seluruh kaum muslimin, maka harta galian tersebut merupakan hak milik umum, sebagaimana firman Allah Subhanahu Wa Ta'ala dalam Al-Qur'an Surah Yasin : 33;

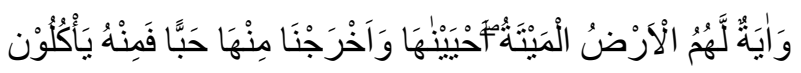

Artinya; Dan suatu tanda (kebesaran Allah) bagi mereka adalah bumi yang mati (tandus). Kami hidupkan bumi itu dan Kami keluarkan darinya bijibijian, maka dari (biji-bijian) itu mereka makan.

\section{Berburu}

Berburu termasuk dalam kategori bekerja. Berburu mutiara, ikan, batu permata, bunga karang serta yang diperoleh dan hasil buruan laut lannya, maka harta tersebut adalah hak milik orang yang memburunya, sebagaimana yang berlaku dalam pemburuan barang dan hewan-hewan 
yang lain. Demikian halnya harta yang diperoleh dari hasil buruan darat, maka harta tersebut adalah milik orang yang memburunya. Sebagaimana firman Allah Subhanahu Wa Ta'ala dalam Al-Qur'an surah Al-Maidah ayat: 96 ;

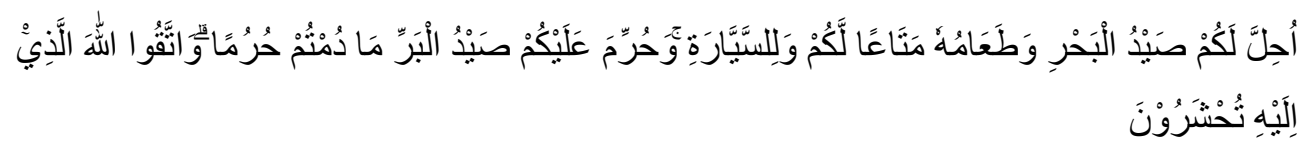

Artinya; Dihalalkan bagimu hewan buruan laut dan makanan (yang berasal) dari laut sebagai makanan yang lezat bagimu, dan bagi orang-orang yang dalam perjalanan; dan diharamkan atasmu (menangkap) hewan darat, selama kamu sedang ihram. Dan bertakwalah kepada Allah yang kepada-Nya kamu akan dikumpulkan (kembali).

Makelar (sam sarah)

Makelar yaitu suatu cara untuk memperoleh harta dengan bekerja untuk orang lain dengan upah, baik itu untuk keperluan menjual maupun membeli. Makelar termasuk dalam kategori bekerja yang bisa dipergunakan untuk memiliki harta, secara hak menurut syara' sebagaimana firman Allah Subhanahu Wa Ta'ala dalam Al-Qur'an surah Yusuf : 72 ;

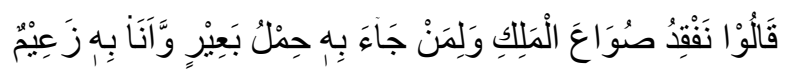

Artinya; Mereka menjawab, "Kami kehilangan piala raja, dan siapa yang dapat mengembalikannya akan memperoleh (bahan makanan seberat) beban unta, dan aku jamin itu."

Syirkah

Syirkah dari segi bahasa bermakna penggabungan dua bagian atau lebih, yang tidak bisa dibedakan lagi antara satu bagian dengan bagian yang lain. Sedangkan menurut syara' syirkah adalah transaksi antara dua orang atau lebih yang dua-duanya sepakat untuk melakukan kerja yang bersifat finansial dengan tujuan mencari keuntungan. 
Ijarah

Ijarah yaitu suatu transaksi jasa yang dimiliki oleh seseorang untuk dikontrak oleh orang lain dengan kompensasi. Hal ini sesuai dengan firman Allah Subhanahu Wa Ta'ala di dalam Al-Qur'an surah At-Talaq : 6 yang berbunyi;

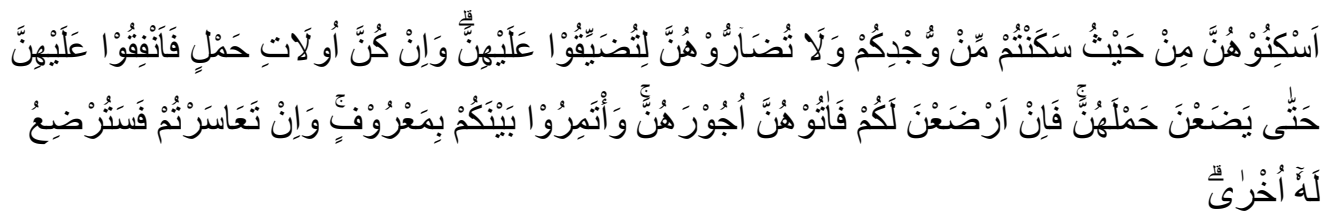

Artinya; Tempatkanlah mereka (para istri) di mana kamu bertempat tinggal menurut kemampuanmu dan janganlah kaтu menyusahkan mereka untuk menyempitkan (hati) mereka. Dan jika mereka (istri-istri yang sudah ditalak) itu sedang hamil, maka berikanlah kepada mereka nafkahnya sampai mereka melahirkan, kemudian jika mereka menyusukan (anak-anak)mu maka berikanlah imbalannya kepada mereka; dan musyawarahkanlah di antara kamu (segala sesuatu) dengan baik; dan jika kamu menemui kesulitan, maka perempuan lain boleh menyusukan (anak itu) untuknya.

b. Waris

Waris juga termasuk dalam kategori sebab atau cara untuk memiliki harta, karena waris adalah sarana untuk membagikan kekayaan yang dimiliki oleh seseorang semasa hidupnya agar tidak mengumpul, maka sebelah kematian orang tersebut, harta itu harus dibagikan atau didermakan kepada orang lain, tetapi pembagian kekayaan tersebut bukanlah merupakan illat bagi waris itu, melainkan sarana tersebut hanya merupakan penjelasan tentang fakta waris itu sendri.

c. Kebutuhan akan harta untuk menyambung hidup

Setiap orang berhak untuk hidup dan juga wajib untuk mendapatkan kehidupan sebagai haknya bukan sebagai hadiah, maupun belas kasihan. Cara ia memenuhinya adalah dengan bekerja, jika tidak mampu bekerja maka negara atau pemerintah wajib untuk mengusahakan pekerjaan untuknya. Karena negara adalah "pengembala" (ar-Ra'i) rakyat, serta 
bertanggung jawab terhadap terpenuhinya kebutuhan-kebutuhan hidup rakyatnya.

d. Pemberian harta negara kepada rakyat

Pemberian ini juga termasuk dalam kategori pemilikan harta yang diberikan kepada orang-orang atau rakyat yang tidak mampu memenuhi hajat kehidupan dan hal ini diambil dari bait al-mal sebagai zakat.

e. Harta yang diperoleh tanpa konpensasi harta dan tenaga

Dalam hal ini yang juga termasuk dalam kategori sebab kepemilikan adalah perolehan individu sebagian mereka dari sebagian yang lain, atas sejumlah harta tertentu dengan tanpa kompensasi harta atau tenaga apapun.

5. Berakhirnya Kepemilikan

Sebab berakhirnya kepemilikan menurut fuqaha, yaitu: pemilik meninggal dunia, sehingga seluruh miliknya berpindah tangan kepada ahli warisnya, harta yang dimiliki itu rusak atau hilang, habisnya masa berlaku pemanfaatan atas sesuatu, barang yang dimanfaatkan rusak atau hilang, dan orang yang memanfaatkan meninggal dunia (Pratanto, 2020). 


\section{PENUTUP}

Dalam Islam kepemilikan dikenal dengan nama al-milkiyah. Al- milkiyah secara etimologi berarti kepemilikan. Al-milkiyah memiliki arti yaitu sesuatu yang dimiliki dan dapat dimanfaatkan oleh seseorang, dan pengertian lain al-milk adalah pemilikian atas sesuatu (al-mal atau harta benda) dan kewenangan seseorang bertindak bebas terhadapnya. Kepemilikan merupakan penguasaan seseorang terhadap sesuatu berupa barang atau harta, baik secara riil maupun secara hukum yang memungkinkan pemilik melakukan tindakan hukum, seperti jual beli, hibah, wakaf, dan sebagainya, yang pada prinsipnya seseorang mempunyai keistimewaan berupa kebebasan dalam berbuat sesuatu atau tidak berbuat sesuatu kecuali ada halangan tertentu yang diakui syara'.

Dalam konsep Islam ada beberapa prinsip dasar tentang kepemilikan, yaitu; kekayaan merupakan titipan dan pemilik yang sebenarnya adalah Allah Subhanahu Wa Ta'ala, harta yang di peroleh dapat menjadi penolong dalam menyempurnakan kewajiban manusia sebagai khalifah di bumi dan juga sarana untuk mendapatkan kesejahteraan dalam kehidupan sekarang maupun kehidupan di hari kemudian, Allah Subhanahu Wa Ta'ala telah melimpahkan kekayaan kepada setiap hamba-Nya untuk dipergunakan menunaikan kewajiban mereka seperti shalat dan zakat, dan Allah Subhanahu Wa Ta'ala telah menetapkan aturan-aturan yang terkait hak-hak kepemilikan, berupa terbatasnya kebebasan individu dan adanya kewajiban untuk mentasharufkan kekayaan kepada orang-orang lain yang berhak.

Adapun kepemilikan dalam Islam itu sendiri, diklasifikasikan menjadi 3 (tiga) jenis, yaitu; kepemilikan individu; kepemilikan umum; dan kepemilikan negara. Sedangkan sebab kepemilikan dalam Islam adalah bekerja (menghidupkan tanah mati, menggali kandungan bumi, berburu, makelar, syirkah, dan ijarah), waris, kebutuhan akan harta untuk menyambung hidup, pemberian harta negara kepada rakyat, serta harta yang diperoleh tanpa konpensasi harta dan tenaga.

Berakhirnya sebuah kepemilikan menurut fuqaha, yaitu: pemilik meninggal dunia, sehingga seluruh miliknya berpindah tangan kepada ahli warisnya, harta yang dimiliki itu rusak atau hilang, habisnya masa berlaku pemanfaatan atas sesuatu, barang yang dimanfaatkan rusak atau hilang, dan orang yang memanfaatkan meninggal dunia. 


\section{DAFTAR PUSTAKA}

Ali, A. (2012). Konsep Kepemilikan Dalam Islam. Jurnal Ushuluddin, XVIII(2), 124140.

Ambok, P. (2011). Kepemilikan Ekonomi Kapitalis Dan Sosialis (Konsep Tauhid Dalam Sistem Islam). Jurnal Kajian Ekonomi Islam Dan Kemasyarakatan, IV(2), 1-19.

Aziz, A. (2019). Harta Dan Kepemilikan. Jurnal Al-Iqtishod, I(1), 1-16.

Muhammad, N. (2016). Sumberdana Dalam Pendidikan Islam (Kepemilikan Harta Dalam Perspektif Islam). Jurnal Al-Murabbi, I(2), 379-398.

Pratanto, R. W. (2020). Konsep Kepemilikan Dalam Islam. Jurnal Irtifaq, VI(1), 73-91.

Sulistiawati, \& Ahmad, F. (2017). Konsep Kepemilikan Dalam Islam (Studi Atas Pemikiran Syaikh Taqiyuddin an-Nabhani). Jurnal Syariah, V(2), 23-52.

Tatty, A. R. (2005). Kepemilikan Pribadi Perspektif Islam, Kapitalis, Dan Sosialis. Jurnal Sosial Dan Pembangunan, XXI(1), 1-13. 